\title{
HONEY BEE AS AN EFFECTIVE POLLINATING AGENT OF PUMPKIN
}

\author{
Daniel Nicodemo ${ }^{1 *}$; Regina Helena Nogueira Couto후 Euclides Braga Malheiros²; David De \\ Jong $^{3}$ \\ ${ }^{1}$ UNESP/FCAV - Depto. de Zootecnia, Campus de Jaboticabal, Via de Acesso Prof. Paulo Donato Castellane \\ s/n - 14884-900 - Jaboticabal, SP - Brasil. \\ ${ }^{2} U N E S P / F C A V$ - Depto. de Ciências Exatas. \\ ${ }^{3}$ USP/FMRP - Depto. de Genética, Av. Bandeirantes, $n^{\circ} 3900$ - 14049-900 - Ribeirão Preto, SP - Brasil. \\ *Corresponding author <nicodemo@fcav.unesp.br>
}

\begin{abstract}
The production of fruits and seeds of many crops is increased when bees visit their flowers pollinating them. The aim of this research was to study the pollination of pumpkins (Cucurbita maxima Duch. var. Exposição), to determine the diversity of insects visiting its flowers, the time and type of provision obtained and the effect of the visits on fruit set, fruit size and weight, and number of seeds. Apis mellifera $\mathrm{L}$. accounted for $73.4 \%$ of the visits made by bees, collecting pollen during $34.5 \mathrm{~s}$ per flower and nectar in $43.9 \mathrm{~s}$ and $29.3 \mathrm{~s}$ from female and male flowers, respectively. Trigona spinipes (Fabr.) collected only nectar, during a mean time of $60.5 \mathrm{~s}$ per flower, and represented $26.6 \%$ of the visits by bees. Diabrotica speciosa (Germ.) only fed on the petals of the flower. When no insect visits occurred, there was no production of fruits. In the flowers with free visitation by insects, fruit set was $40 \%$. The higher the number of visits, up to 16, by A. mellifera to female flowers, the greater was the fruit set, fruit size and weight, and number of seeds. In flowers visited by insects from the onset of anthesis until 9 a.m., fruit set was $35 \%$. After 9 a.m., there was no fruit set, demonstrating the important role of A. mellifera as a pollinating agent of pumpkin, since it was the only insect visiting up to 9 a.m.
\end{abstract}

Key words: Cucurbita maxima, pollination, honey bee

\section{ABELHAMELÍFERACOMO EFICIENTEAGENTE POLINIZADOR DE MORANGA}

\begin{abstract}
RESUMO: A produção de frutos e sementes de várias culturas é favorecida quando abelhas visitam suas flores, efetuando a polinização. O objetivo deste trabalho foi estudar a polinização em moranga (Cucurbita maxima Duch. var. Exposição), no que se refere à identificação dos insetos que visitam mais freqüentemente suas flores, o tempo e tipo de recurso floral coletado e o resultado das visitas destes insetos na frutificação, tamanho, peso e número de sementes dos frutos. Apis mellifera L. foi responsável por $73.4 \%$ das visitas realizadas por abelhas, coletando pólen em 34.5 s e néctar em 43.9 s e 29.3 s, respectivamente para as flores femininas e masculinas. Trigona spinipes (Fabr.) coletou apenas néctar, em tempo médio de $60.5 \mathrm{~s}$, representando $26.6 \%$ das visitas realizadas por abelhas. Diabrotica speciosa (Germ.) somente se alimentou das pétalas da flor. Não houve produção de frutos quando não ocorreu visita de insetos. Nas flores com livre visitação de insetos a frutificação foi de $40 \%$. Quanto maior o número, até 16, de visitas de A. mellifera nas flores femininas, maior a frutificação, tamanho, peso e número de sementes. A frutificação foi de $35 \%$ no tratamento em que as flores permaneceram disponíveis à visitação desde o início da antese até às 9 h00. A partir deste horário não houve frutificação, evidenciando o importante papel da A. mellifera como agente polinizador da moranga, já que foi o único inseto visitante até às 9 h00.

Palavras-chave: Cucurbita maxima, polinização, abelha africanizada
\end{abstract}

\section{INTRODUCTION}

The destruction of natural habitats has reduced the nidification sites of various pollinating agents, affecting drastically their population. Many plant species depend on these agents for their production. Moreover, intensive farming has not only increased the demand for pollinators but also negatively affected their density and diversity (Nogueira-Couto, 2002).

Growers in some regions of Brazil have suffered with the decline in the production of fruits, especially those that have crops close to an urban area (Boti et al., 2005). Considering the importance of pollination in the establishment and production of fruits in vari- 
ous crops and the reduction in the diversity and abundance of pollinating agents, it is necessary to evaluate the need of controlled pollination of crops dependent on pollinating agents (Fonseca et al., 2006).

In Brazil, there are few reports on the pollination of crops of major commercial importance, and pumpkin (Cucurbita maxima Duch.) is one of the main ones. Pumpkin originated in Central America (Hartmann et al., 1988) is of great economic interest, being used as food among humans, as energy source and as animal feed, as a source of Beta-carotene.

Apis mellifera L. bees are effective pollinating agents of cucurbits (Thompson et al., 1955; Whitaker \& Davis, 1962; Hurd, 1964; Couto et al., 1990). In the USA, Peponapis pruinosa has been shown to be the most important pollinating agent of pumpkins (Flottum, 2000). Bombus terrestris (L.) is also an effective pollinating agent of pumpkins (Fuchs \& Müller, 2004).

The objective of this study was to evaluate pollination in pumpkins, variety Exposição, to determine the density and diversity of pollinators foraging on flowers, their behavior on the flowers and their resultant effects in terms of fruit production.

\section{MATERIALAND METHODS}

The experiments were carried with pumpkin ( $C$. maxima), variety Exposição, in 2001 and 2002. A pumpkin crop was cultivated in Jaboticabal, State of São Paulo, Brazil (2115’22”'S, 48¹8’58’'W, altitude 595 $\mathrm{m})$. The area has a temperate subtropical climate, and a mean annual temperature of $21^{\circ} \mathrm{C}$. The mean annual rainfall is $1431 \mathrm{~mm}$. The region is intensively farmed with sugar cane being the dominant crop. Forests are reduced and fragmented, and the closest to the experimental area is more than $3 \mathrm{~km}$ away. An apiary with 30 hives was installed near the experimental area.

Soil analysis was performed in 2002 and afterwards the soil was limed in accordance with the recommendations for fertilizing and liming of the State of São Paulo (Raij et al., 1996), which differed from the preceding year when no lime was applied. In both years 128 pumpkin plants were grown with a spacing $3 \mathrm{~m}$ between plants and rows. Due to the lack of rain, plants were watered weekly.

Frequency of visitations by the insects, from $6 \mathrm{~h} 00$ to $18 \mathrm{~h} 00$, was made through visual observation by counting every 50 min from the start of visitation, for 10 min each hour, at the experiment site, with four replicates during different periods of each year.

In 2001 and 2002, during the flowering period, the most frequent insects were collected and preserved for later identification. The time and type of harvest (nectar and/or pollen) were determined for the most fre- quently appearing insects, at different hours, with 30 replicates, on four days of each test.

To obtain fruit production with and without visits by insects, 20 female flowers were chosen randomly before anthesis and marked, where half were covered with nylon bags which impeded visits by insects and the other half left uncovered with open pollination by insects. In the test, the edges of the patch were avoided, and five replicates were carried out for a total of 100 flowers per test. To determine the pollinating effectiveness of A. mellifera, female flowers were covered in pre-anthesis and uncovered in anthesis to allow visits exclusively by this species at pre-established frequencies (two, four, eight and 16 visits). Twenty flowers (replicates) were used for each frequency (treatment) of visits. Therefore, 80 flowers were utilized (four levels of visits $\times 20$ replicates per test. The time of each visit by $A$. mellifera bees was recorded. The visits were permitted between 8h00 and 10h00. In each plant, only one flower per branch received visits and the flowers were randomly chosen for the treatments in a completely randomized design. After each visit, the flowers were labeled, protected again and establishment of fruit evaluated five days after the visitation, when the development of the ovary or abscission of the flower was observed. Fruits were removed when they reached commercial size. The method used followed Danka et al. (1983) \& Stanghellini et al. (1997).

In 2002, a test was carried out to determine the effectiveness of visits by A. mellifera at different hours. Female flowers were protected before anthesis and left unprotected after anthesis to allow visits by the bees at four different visitation periods. In the first treatment, the flowers were uncovered after anthesis and covered again for $9 \mathrm{~h}$. In the second treatment, the flowers were uncovered at $10 \mathrm{~h} 00$ and covered again at $11 \mathrm{~h} 00$. In the third treatment, the flowers were uncovered for $13 \mathrm{~h}$ and left that way. In the fourth treatment, the flowers received free visitation during the whole day. Each treatment included 20 flowers (replicates), totaling 80 flowers for four levels of visits $\times 20$ replicates.

Time of fruit formation was determined, which was from fruit bud to the mature fruit, observing the percentage of fruit set in the treatments in which the female flowers remained covered or uncovered, with ten replicates for each treatment for each test. The size of each fruit was also measured. Fruits were weighed and examined with respect to the number of seeds per fruit. A similar analysis was carried out relative to the number of visits by A. mellifera per flower.

The experimental design utilized was completely randomized. Spearman's correlation was used to determine if fruit size and weight and number of seeds correlated with the number of visits. Student's $t$ test was utilized 
for the comparison of fruits derived from flowers with free visitation and those that received 16 visits. Data were processed with the SAS program (1993).

\section{RESULTS AND DISCUSSION}

During the two years, A. mellifera, Diabrotica speciosa (Germ.) and Trigona spinipes (Fabr.) were the most frequent insects on the flowers of pumpkin plants. The peak presence of $A$. mellifera occurred at $8 \mathrm{~h} 00$, for T. spinipes from $9 \mathrm{~h} 00$ to $10 \mathrm{~h} 00$, and for $D$. speciosa from $14 \mathrm{~h} 00$ to $17 \mathrm{~h} 00$, with no overlapping of these peak hours (Figure 1). A. mellifera visited the flowers to collect nectar and pollen, T. spinipes to collect exclusively nectar, and $D$. speciosa to feed on the flower petals. Considering only the bees A. mellifera and $T$. spinipes, their visits represented respectively $67.6 \%$ and $32.4 \%$ for the first year and $79.2 \%$ and $20.8 \%$ for the second year. A. mellifera, T. spinipes and $D$. speciosa were the insects most frequently found on pumpkin flowers in both years. A greater number of visits occurred early in the day with higher temperatures, but on colder days the visitation period lasted longer (Table 1).
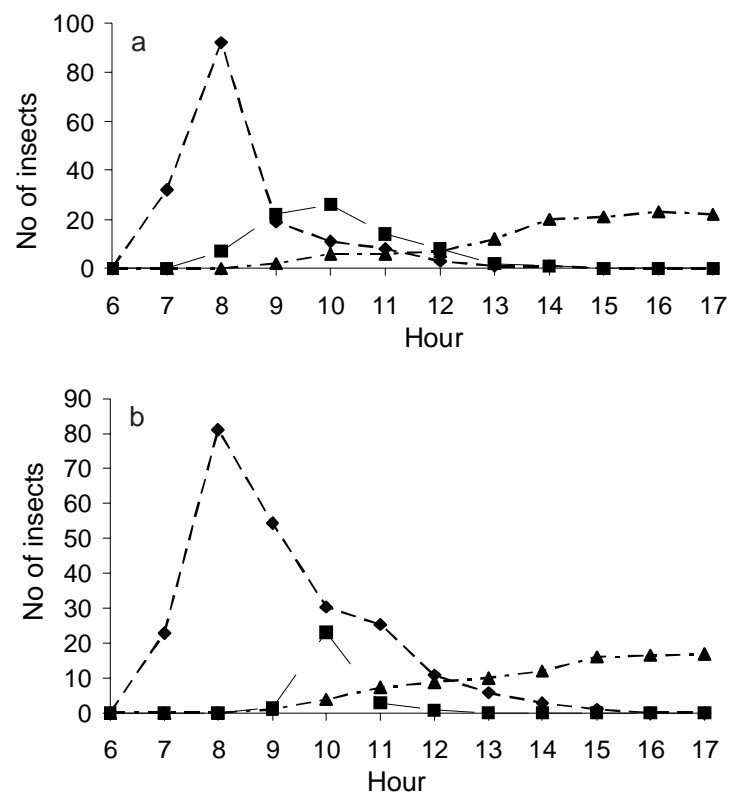

$-\bullet$ Apis mellifera $\longrightarrow$ Trigona spinipes $-\bullet--$ Diabrotica speciosa

Figure 1 - Most frequent insects found on flowers of pumpkin (Cucurbita maxima), at different hours in 2001 (A) and 2002 (B).
The time of collection spent on each flower was different between years and between male and female flowers. The mean time of visit for A. mellifera per flower was $36 \pm 5.6 \mathrm{~s}$ and $20 \pm 4.4 \mathrm{~s}$ in 2001 and $51.8 \pm 7.5 \mathrm{~s}$ and $38.6 \pm 3.9 \mathrm{~s}$ in 2002 , respectively for the harvest of nectar in female and male flowers, indicating that these bees spent more time collecting nectar in the female flowers. Generally, in diclinous monoecious plants, the female flowers produce more nectar than the male flowers (Nicodemo et al., 2007). It is possible that this is a strategy to attract insects since the male flowers offer pollen besides nectar. For the polen harvest, the results were not different between years. The time of visit of A. mellifera was $36.0 \pm 8.1 \mathrm{~s}$ and $33.0 \pm 4.6 \mathrm{~s}$, respectively for the first and second years. T. spinipes collected only nectar in a mean time of 58 and $63 \mathrm{~s}$, respectively in 2001 and 2002. D. speciosa harvested neither nectar nor pollen, and when it was on the female flower it did not come in contact with the stigma due to its small size, feeding only on the flower petals.

The time of fruit formation was 53 and 65 days after blooming respectively for the first and second year. The fruit was harvested when it presented the characteristic orange color and dry peduncle. When no visits by insects occurred on the flowers, there was no production of fruits (Table 2). With free visitation, fruit production was 38 and 42\% in 2001 and 2002, respectively. In Cucurbita pepo, there is no production of fruits without visitation of flowers by insects (Couto et al., 1990).

With a greater number of visits by A. mellifera on the flowers, fruit set was increased, up to 16 visits per female flower. In the first year, the width of the fruits was greater in those from flowers that received a greater number of visits by A. mellifera, but there was no difference for the other observed parameters (Table 3). In the second year, there was a difference for length, width, number of seeds and mainly weight of the fruits $(r=0.85)$, where such characteristics benefited from the greater number of visits by A. mellifera. The resultant fruits of flowers that received 16 visits had double the weight of fruits resulting from flowers that were visited twice. Apparently, not only the number of visits is important for fruit production but also the time and type of harvest, because the longer the visit, the greater the chance of the insect coming in contact with the stigma of the flower.

Table 1 - Mean temperature of the days when insects were observed visiting the flowers of pumpkin.

\begin{tabular}{|c|c|c|c|c|c|c|c|c|}
\hline \multirow{3}{*}{$\begin{array}{l}\text { Year } \\
\text { Month } \\
\text { Days }\end{array}$} & \multicolumn{4}{|c|}{2001} & \multicolumn{4}{|c|}{2002} \\
\hline & \multicolumn{4}{|c|}{ August } & \multicolumn{4}{|c|}{ July } \\
\hline & 18 & 19 & 25 & 26 & 23 & 24 & 25 & 26 \\
\hline Mean temperature $\left({ }^{\circ} \mathrm{C}\right)$ & 19.8 & 20.2 & 21.0 & 21.3 & 19.9 & 20.2 & 20.5 & 21.1 \\
\hline
\end{tabular}


Table 2 - Resulting fruit set of pumpkin from 50 flowers covered and 50 flowers with free visitation, in 2001 and 2002.

\begin{tabular}{|c|c|c|c|c|c|c|}
\hline \multirow[t]{2}{*}{ Treatment } & & Fruit set & Length & Width & Weight & No. of seeds \\
\hline & & $\%$ & - - - - & - - - - & $\mathrm{g}$ & \\
\hline \multirow[t]{2}{*}{2001} & Covered & 0 & - & - & - & - \\
\hline & Uncovered & 38 & 172.1 & 86.66 & 1133.7 & 130 \\
\hline \multirow[t]{2}{*}{2002} & Covered & 0 & - & - & - & - \\
\hline & Uncovered & 42 & 181.8 & 101.9 & 1727.4 & 162.81 \\
\hline
\end{tabular}

Table 3 - Fruit set of pumpkin resulting from flowers that received 2, 4, 8 and 16 visits by Apis mellifera, ( 80 flowers), time of visit, Spearman's correlation coefficient (r) and $p$ value, in 2001 and 2002.

\begin{tabular}{|c|c|c|c|c|c|c|}
\hline Treatment & Fruit set & Length & Width & Weight & No. of seeds & Mean time of visit \\
\hline & $\%$ & - & - & $\mathrm{g}$ & & $\mathrm{s}$ \\
\hline \multicolumn{7}{|c|}{2001} \\
\hline 2 visits & 5 & 148.2 & 84.1 & 820 & 148.0 & 43 \\
\hline 4 visits & 5 & 163.9 & 89.6 & 1.140 & 184.0 & 41 \\
\hline 8 visits & 15 & 161.9 & 87.5 & 1.087 & 207.3 & 35 \\
\hline 16 visits & 55 & 160.7 & 98.1 & 1.202 & 188.2 & 34 \\
\hline$r$ & - & 0.07 & 0.61 & 0.23 & 0.61 & - \\
\hline$p$ & - & $>0.20$ & 0.01 & $>0.20$ & $>0.81$ & - \\
\hline \multicolumn{7}{|c|}{2002} \\
\hline 2 visits & 15 & 152.3 & 93.7 & 963.3 & 82.3 & 48 \\
\hline 4 visits & 15 & 162.0 & 108.0 & 1086.0 & 106.7 & 43 \\
\hline 8 visits & 25 & 184.2 & 110.4 & 1613.0 & 143.6 & 36 \\
\hline 16 visits & 45 & 188.0 & 115.8 & 1932.9 & 175.1 & 30 \\
\hline$r$ & - & 0.71 & 0.51 & 0.85 & 0.76 & - \\
\hline$p$ & - & $<0.01$ & 0.02 & $<0.01$ & $<0.01$ & - \\
\hline
\end{tabular}

The mean weight of all the fruits in the second year was greater than that for the first year, possibly due to the liming and also because the plants lasted 12 days longer than in the preceding year. As fertilizer conditions were better on the second year, the fruits became larger than the fruits from 2001 and for that the plants needed more time. In the two years, fruit set for the treatment with free visitation was less than for the treatment with 16 visits. This occurred because there could have been less than or more than 16 visits with visitation. Considering the possibility of more than 16 visits, there is some indication that excessive visitation can lead to the removal of pollen grains already deposited on the stigma of the flowers. With pollination, up to $74.6 \%$ fruit set can be obtained in pumpkins, where the climatic conditions are secondary when compared to the importance of the bees in fruit establishment (Stapleton et al., 2000).

The fruits from flowers that had 16 visits had a greater width $(p=0.04)$ and number of seeds $(p=0.01)$ in 2001 than the fruit resulting from flowers with free visitation which in turn had greater width
( $p=0.03$ ) in 2002, based on Student's t test. There was no difference for the other comparisons between these two treatments. Walters \& Taylor (2006) studied the pollination of Cucurbita pepo, C. moschata and C. maxima and concluded that despite the presence of sufficient numbers of pollinating insects of pumpkin at the experiment location, fruit set, fruit size and weight and number of seed was greater when hives of A. mellifera were installed among the crops. Walters \& Taylor (2006) noted that since pumpkins are sold by weight, the grower's earnings could be greater when A. mellifera hives are installed during the flowering of pumpkin plants. To know that, it is necessary to estimate the costs to rent honey bee colonies for pumpkin pollination.

The flowers open to visitation until 9h00 originated fruits with $35 \%$ fruit set, $171.14 \mathrm{~mm}$ in length, 100.29 $\mathrm{mm}$ in width, weight of $1,340 \mathrm{~g}$ and 120.57 seeds. However, the flowers open from $10 \mathrm{~h} 00$ to $11 \mathrm{~h} 00$ and from 13h00, did not give rise to any fruit. These findings demonstrate the efficacy of A. mellifera as a pollinating agent of pumpkin, since it is the only insect that visited the flowers until $9 \mathrm{~h}$. 


\section{CONCLUSIONS}

The most important insect seen on flowers of pumpkin was A. mellifera, which harvested nectar and pollen. T. spinipes harvested nectar and $D$. speciosa sucked the sap from the petals. Both did not pollinate pumpkin flowers. A. mellifera is an effective pollinating agent of the pumpkin crop. Fruit production occurs only when the insects visit the flowers up to $9 \mathrm{~h}$. Fruit set, fruit size and weight and number of seed increased as the number of visits by A. mellifera also increased up to 16 visits per female flower, at which the highest fruit set level was reached.

\section{ACKNOWLEDGMENTS}

To FAPESP and CNPq, for the Scholarship and other support.

\section{REFERENCES}

BOTI, J.B.; CAMPOS, L.A.O.; MARCO, P.; VIEIRA, M.F. Influência da distância de fragmentos florestais na polinização da goiabeira. Revista Ceres, v.52, p.863-874, 2005.

COUTO, R.H.N.; PEREIRA, J.M.S.; COUTO, L.A Estudo da polinização entomófila em Cucurbita pepo (abóbora italiana). Científica, v.18, p.21-27, 1990.

DANKA, R.G.; LANG, G.A.; GUPTON, C.L. Honey bee (Himenoptera: Apidae) visits and pollen source effects on fruiting of "Gulfcoast" southern highbush blueberry. Horticultural Entomology, v.86, p.131-136, 1983.

FONSECA, V.L.I.; SARAIVA, A.M.; DEJONG, DAVID. Bees as pollinators in Brazil. Ribeirão Preto: Holos, 2006, 112p.

FLOTTUM, K. Pollination 2000. Bee Culture Magazine, v.36, p.12, 2000.
FUCHS, R.; MÜLLER, M. Pollination problems in Styrian oil pumpkin plants: Can bumblebees be an alternative to honeybees? Phyton, v.44, p.155-165, 2004.

HARTMANN, H.T.; KOFRANEK, A.M.; RUBATZKY, V.E.; FLOCKER, W.J. Plant science: growth, development, and utilization of cultivated plants. Englewood Cliffs: Prentice-Hall, 1988. 482p.

HURD, P.D. The pollination of pumpkins, gourds and squashes (genus Cucurbita). Bee World, v.47, p.97-98. 1964.

NICODEMO, D.; COUTO, R.H.N.; MALHEIROS, E.B.; DEJONG, D. Biologia floral em moranga (Cucurbita maxima Duch. Var. Exposição). Acta Scientiarum Agronomy, v.29, p.611-616, 2007.

NOGUEIRA-COUTO, R.H. Plantas e abelhas, uma parceria em crise? In: ENCONTRO SOBRE ABELHAS, 5., Ribeirão Preto, 2002. Anais. Ribeirão Preto: USP, 2002. p.87-94.

RAIJ, B. van; CANTERELLA, H.; QUAGGIO, J.A.; FURLANI, A.M.C. Recomendações de adubação e calagem para o Estado de São Paulo. 2 ed. Campinas: Instituto Agronômico (Boletim Técnico, 100), 1996, 285p.

SAS INSTITUTE. Statistical analysis systems: user's guide; version 6.12. 4 ed. Cary: SAS Institute, 1993.

STANGHELLINI, M.S.; AMBROSE, J.T.; SCHULTEIS, J.R. The effects of honey bee and bumble bee pollination on fruit set and absorption of cucumber and watermelon. American Bee Journal, v.137, p.386-391, 1997.

STAPLETON, S.C.; WIEN, H.C.; MORSE R.A. Flowering and fruit set of pumpkin cultivars under field conditions. Hortscience, v.35, p.1074-1077, 2000.

THOMPSON, R.C.; DOOLITTLE, S.P.; CAFFREY, D.J. Growing pumpkins and squashes. USDA Farmers' Bulletin, v.2086, p.1-30, 1955 .

WALTERS, S.A; TAYLOR, B.H. Effect of honey bee pollination on pumpkin fruit and seed yield. Hortscience, v.41, p.370373, 2006

WHITAKER, T.W.; DAVIS, G.N. Cucurbits: botany, cultivation, and utilization. London: Leonard Hill Books, 1962. 240p.

Received December 17, 2007

Accepted December 15, 2008 